This document was prepared in conjunction with work accomplished under Contract No.

DE-AC09-96SR18500 with the U. S. Department of Energy.

\title{
DISCLAIMER
}

This report was prepared as an account of work sponsored by an agency of the United States Government. Neither the United States Government nor any agency thereof, nor any of their employees, makes any warranty, express or implied, or assumes any legal liability or responsibility for the accuracy, completeness, or usefulness of any information, apparatus, product or process disclosed, or represents that its use would not infringe privately owned rights. Reference herein to any specific commercial product, process or service by trade name, trademark, manufacturer, or otherwise does not necessarily constitute or imply its endorsement, recommendation, or favoring by the United States Government or any agency thereof. The views and opinions of authors expressed herein do not necessarily state or reflect those of the United States Government or any agency thereof.

This report has been reproduced directly from the best available copy.

Available for sale to the public, in paper, from: U.S. Department of Commerce, National Technical Information Service, 5285 Port Royal Road, Springfield, VA 22161, phone: (800) 553-6847, fax: $(703) 605-6900$

email: orders@ntis.fedworld.gov

online ordering: http://www.ntis.gov/ordering.htm

Available electronically at http://www.doe.gov/bridge

Available for a processing fee to U.S. Department of Energy and its contractors, in paper, from: U.S. Department of Energy, Office of Scientific and Technical Information, P.O. Box 62, Oak Ridge, TN 37831-0062,

phone: (865)576-8401,

fax: (865)576-5728

email: reports@adonis.osti.gov 


\section{PLUTONIUM IMMOBILIZATION PROJECT - ROBOTIC CANISTER LOADING}

\author{
E. Lee Hamilton \\ Westinghouse Savannah River Co. \\ Building 773-A \\ Aiken, SC 29808 \\ (803) 725-3472
}

\author{
Dr. Gregory L. Hovis \\ Westinghouse Savannah River Co. \\ Building 773-A \\ Aiken, SC 29808 \\ (803) 725-1180
}

\author{
Mitchell W. Stokes \\ Westinghouse Savannah River Co. \\ Building 723-A \\ Aiken, SC 29808 \\ (803) 725-1684
}

\section{ABSTRACT}

The Plutonium Immobilization Project (PIP) is a joint venture between the Savannah River Site (SRS), Lawrence Livermore National Laboratory (LLNL), Argonne National Laboratory (ANL), and Pacific Northwest National Laboratory (PNNL). When operational in 2008, the PIP will fulfill the nation's nonproliferation commitment by placing surplus weapons-grade plutonium in permanently stable ceramic forms that will be encapsulated within canisters containing high level waste glass to make it unattractive for reuse. Since there are significant radiation and security concerns, the project team is developing unique technologies to remotely perform plutonium immobilization tasks. The remote task covered in this paper employs a jointed arm robot to load seven $3.5 "(89 \mathrm{~mm})$ diameter, $135 \mathrm{lb} .(61 \mathrm{~kg})$ cylinders (magazines containing cans of ceramic pucks) through the 4" $(102 \mathrm{~mm})$ diameter throat of a stainless steel canister. Working through the narrow canister throat, the robot secures the magazines into a specially designed rack preinstalled in the canister. To provide theft deterrent, the canisters are subsequently filled with high level radioactive waste glass. This operation will be performed at the Defense Waste Processing Facility (DWPF), which began operating in 1996.

\section{PROCESS DESCRIPTION}

"Can-in-Canister" (CIC) refers to the system for immobilizing and protecting excess plutonium in the PIP. Five components work together to form the system - the puck, puck can, magazine, rack and DWPF canister. (Figure 1 is a photograph of the prototypical magazine.) The plutonium oxide-ceramic puck is the basic component of the immobilization scheme. Twenty pucks are placed in each 20 " $(0.5 \mathrm{~m})$ long puck can and sealed by a remote welding process. Automated equipment then inserts four sealed puck cans into each magazine and closes the magazine with a mechanical, snap-type permanent closure. Other automated equipment then takes magazines to a staging area for canister loading..
In the staging area, a DWPF canister with pre-installed rack is brought into the facility on an automated cart. A three degree-of-freedom telescoping bridge robot with a three degree-of-freedom manipulator obtains a loaded magazine from the staging area and carries the magazine to the canister. The robot then lowers the magazine through the canister throat until it is entirely inside the canister. At this point, the operator uses remote viewing and manual control to align the magazine radially with a socket and place the magazine into a storage position on the rack. The robot then indexes from the first magazine and repeats the process with six additional magazines until all seven rack positions are occupied. Loaded canisters are then taken to the DWPF, where they are filled with a molten mixture of high level radioactive waste glass and welded closed. After cooling, the canisters are inspected and sent to an interim storage facility with planned final storage in a federal repository.

\section{EQUIPMENT DESCRIPTION}

\section{A. MAGAZINE}

Magazines hold the puck cans in place during remote operations and later in the DWPF facility when the glass mixture is poured into the canister. Magazines are made of 3" Schedule-10 304L stainless steel pipe. They are 7-feet $(2 \mathrm{~m})$ long, have a 3.5inch $(89 \mathrm{~mm})$ outside diameter and weigh 135 pounds $(61 \mathrm{~kg})$ [loaded]. At the top of the magazine is a gripper knob and at the bottom is a cone-shaped device to assist in guiding the magazine into the magazine rack. The most noticeable feature of the magazines is the laser-cut slots. During pouring, glass

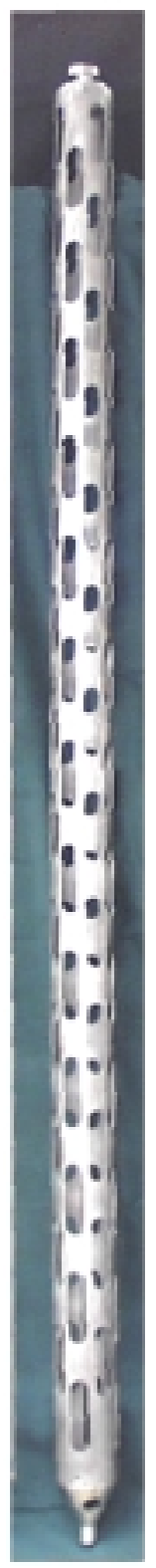

Figure 1: Magazine 
flows through the slots and contacts the puck cans, forming a void-free glass-metal matrix surrounding the puck cans.

The current slotted pipe magazine is the result of an intense search for the optimum combination of handling and glass-flow characteristics. Remoteability concerns favor a dimensionally consistent, structurally robust magazine that deflects minimally during loading operations, i.e. fabricated from pipe. However, glass flow is optimized with a magazine that offers minimal obstruction to molten glass so that glass completely surrounds the puck cans, penetrating even the smallest crevices. The ideal magazine for glass flow is one that maximizes open area, such as a welded wire or wire mesh design. Early handling tests on six different wire magazine designs revealed that they were either too fragile, too costly or too dimensionally inconsistent to meet design requirements. Therefore, the team focused on finding an ideal pipe magazine. Scoping tests with non-radioactive glass were conducted at South Carolina's Clemson Environmental Technology Center (CETL) to see how magazine configuration impacted glass flow. Pipe magazines with three different wall thicknesses and three different perforation configurations were tested, along with welded wire and wire mesh magazines. In all cases, glass completely filled magazine crevices, and wire magazines showed no advantage over pipe designs. Subsequently, the team chose a magazine design produced from common 3" schedule $10(89 \mathrm{~mm}$ OD) stainless pipe with laser-cut slots that offers ideal remoteability characteristics (light weight and stiffness).

\section{B. RACK}

A pre-installed framework, or "rack," (Figure 2) inside the DWPF canister determines final loaded positions for the seven magazines. The rack serves several purposes:

- keeps the magazines in a predetermined, symmetric orientation inside the canister and allows glass to flow around puck cans to encapsulate them

- provides both lateral and vertical latching to reduce the possibility of magazines leaving their positions during transport to DWPF and glass pouring

- lends strength during canister handling, transportation, and glass pouring

The rack is designed to provide adequate structural support while minimizing both mass and resistance to glass flow. It is constructed entirely of stainless steel and consists of four scalloped plates and one bottom plate joined by seven solid round bars. The bottom plate is supported above the bottom of the canister with seven radial struts. Like the magazines, the struts and bottom plate have large openings to permit unobstructed glass flow. Seven "sockets" in the bottom plate (Figure 3) provide the resting surface for magazines. The sockets accept the cones at the bottom of each magazine. Snap rings at the cone/socket interface (not shown in photos) constrain the magazine vertically, while unique butterfly latches on the scalloped plates constrain lateral movement. (The operation of the lateral latches is described on the next page in the frames of Figure 4.)

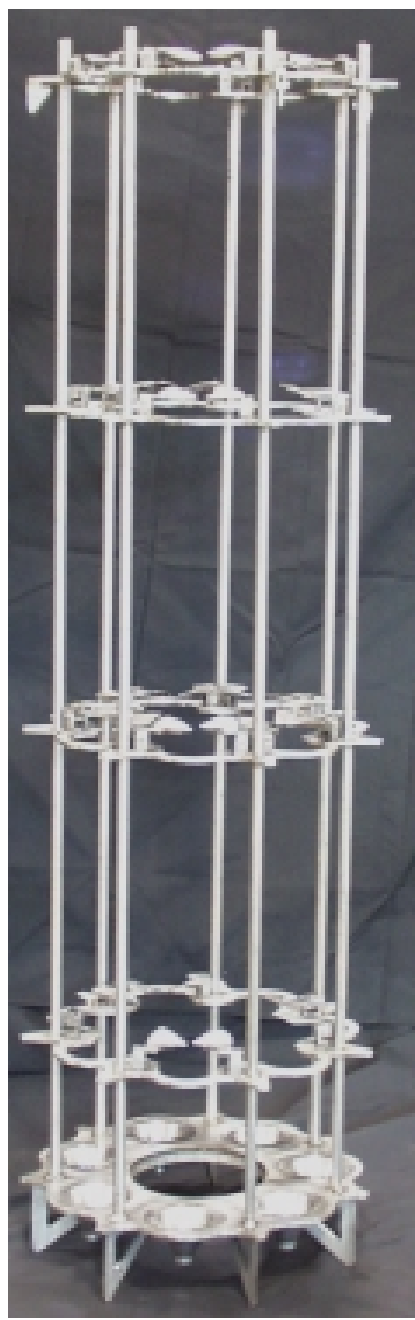

Figure 2: Typical rack

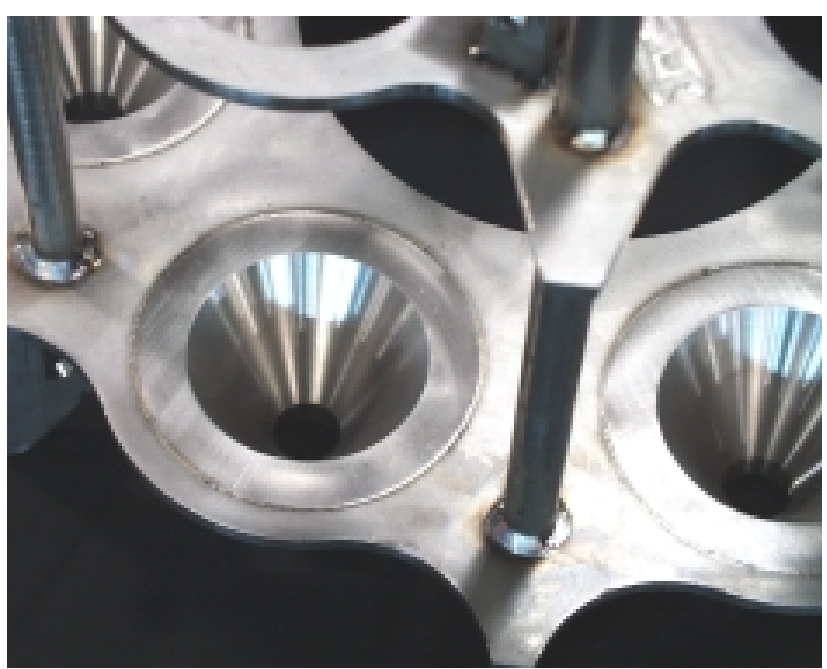

Figure 3: Sockets (Snap ring groove for vertical latch not shown.) 


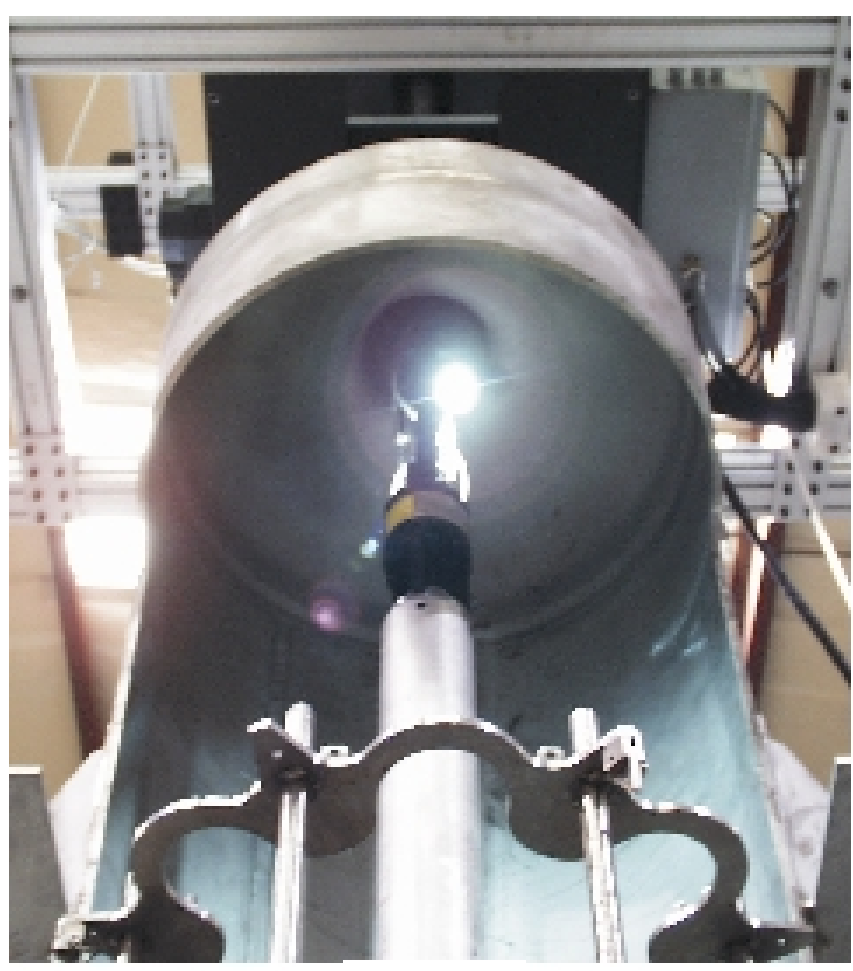

Step 1

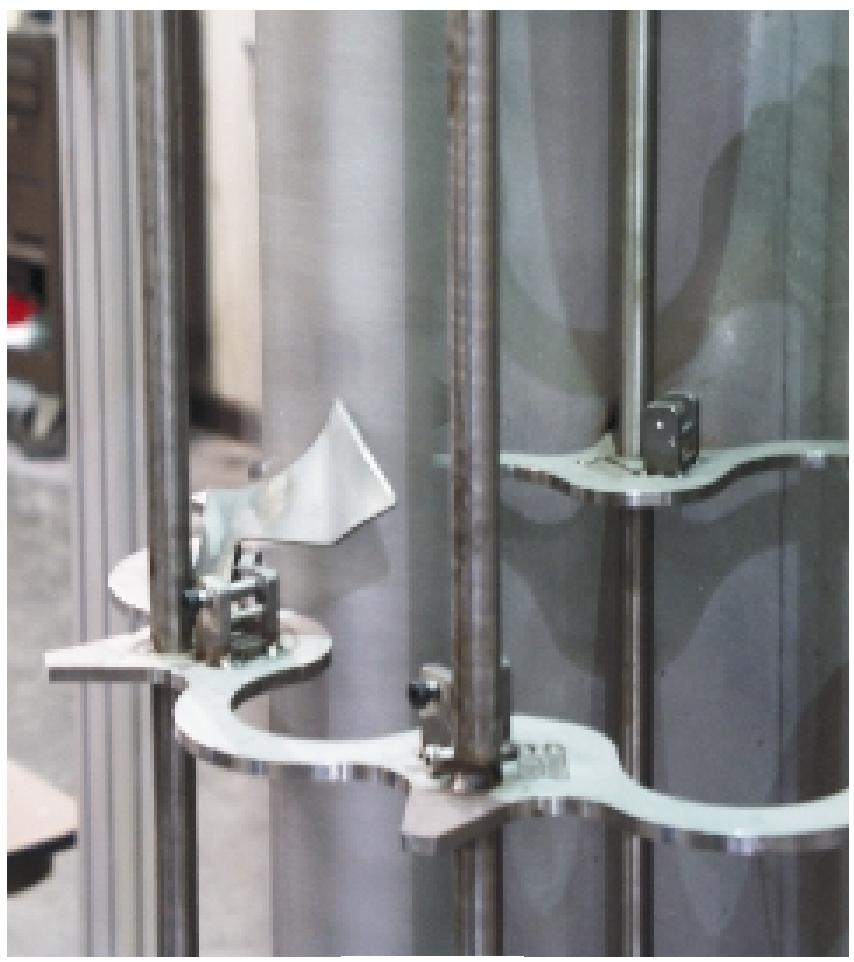

Step 3

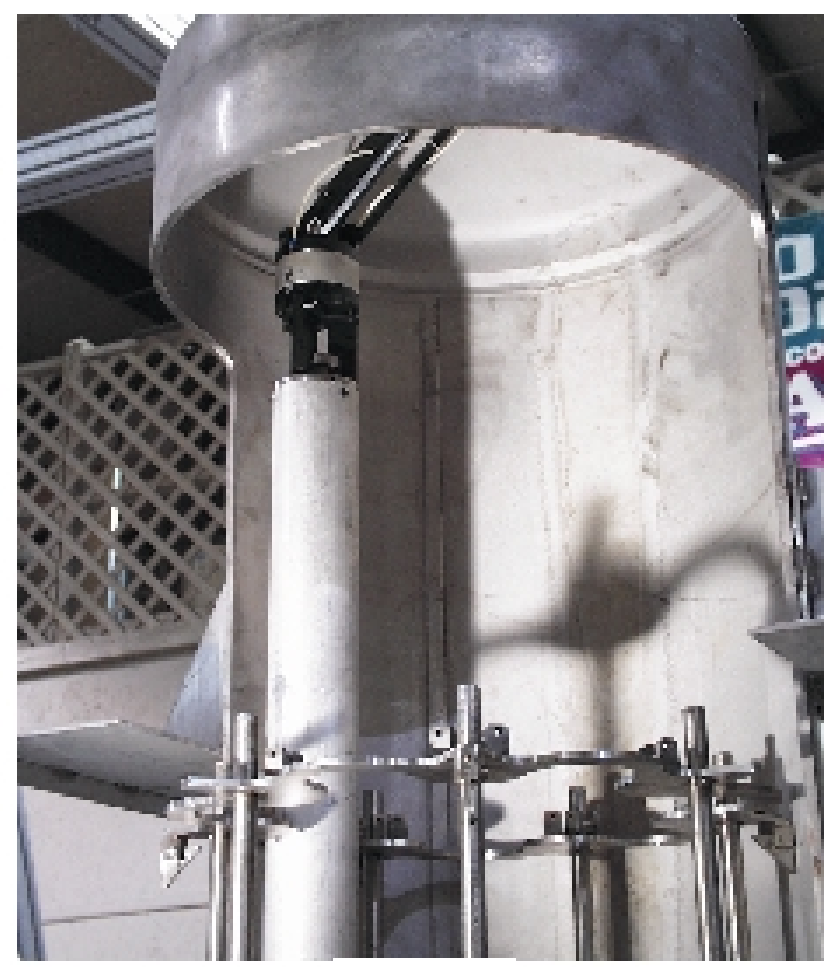

Step 2

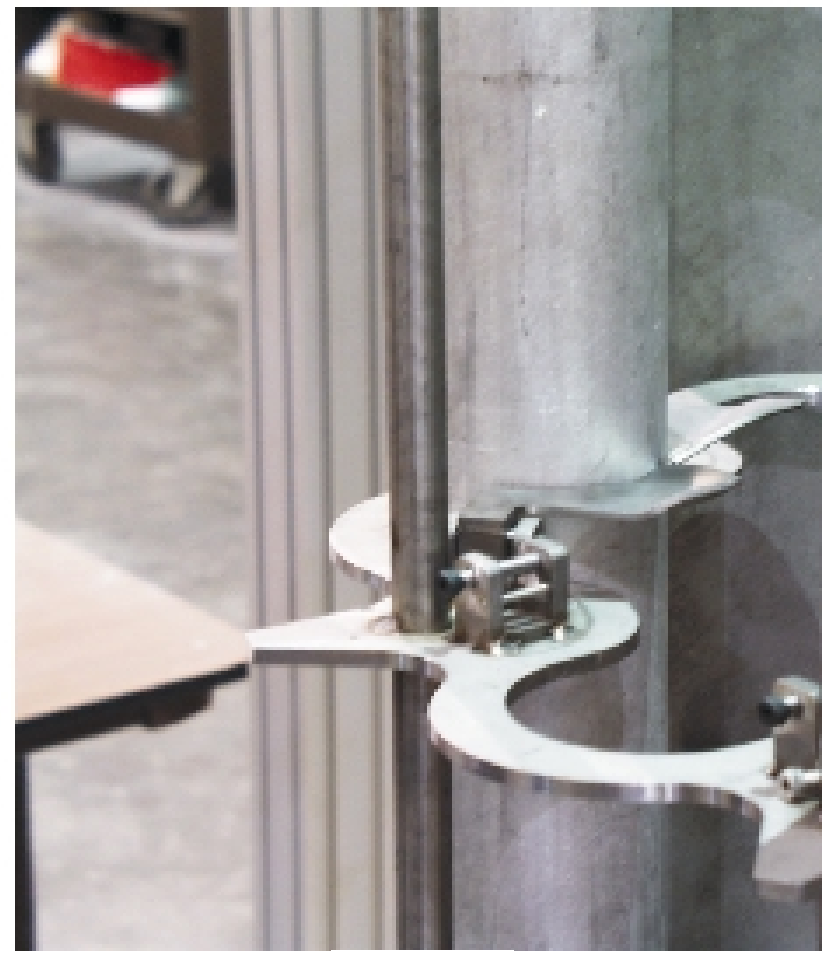

Step 4

Figure 4: Step 1 shows the magazine lowered into the canister. [The white spot is the light source for remote viewing inside the canister.] In Step 2, the operator rotates the arm to align the magazine with the latches mounted in the storage rack using miniature cameras mounted on the arm. In Step 3, the manipulator arm pivots to engage the magazine into the lateral latches. Step 4 shows the latch engaged with the magazine seated in the socket. 
Three racks were fabricated and tested at CETL with non-radioactive glass. The racks performed as designed and did not deform or impede glass flow around the puck cans.

\section{CANISTER LOADING ROBOT}

The Canister Loading Robot is uniquely designed for the canister loading process. It is a three degree-offreedom telescoping bridge robot with a three-degree-of-

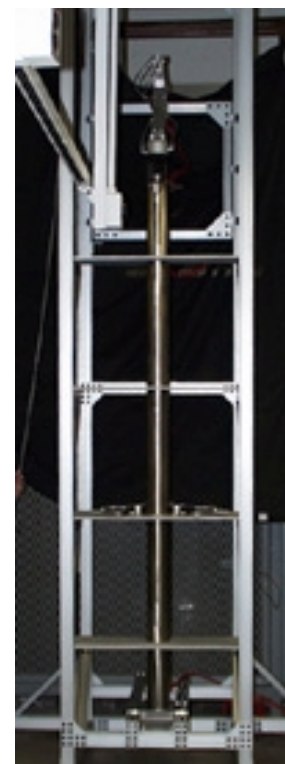

Figure 5: Test stand with pipe magazine freedom manipulator. While in the loading position, canisters are stationary, in a vertical orientation, and do not rotate. Therefore the Canister Loading Robot must provide all movement necessary to load magazines into a canister and lock the magazines to the rack. This ship-in-a-bottle approach to canister loading begins when the robot inserts the loaded magazine into the canister throat. The robot is capable of three motions once inside the canister: tilt, rotation and vertical translation. During loading operations, rotation is used to align the magazine radially with a socket. Then tilt is used to rotate the magazine through the rack's butterfly latches, and finally the vertical translation is used to lower the magazine to its stored position. The wrist holding the gripper is constrained to ensure the magazine remains vertical at all times. It does this through a 4-bar link to the robot mast.

The canister loading robot has not yet been built, however three mockups were constructed and operated to demonstrate feasibility. The first mockup [Figure 5] was a stationary test stand that contained a magazine and a single socket. It had an articulated arm that was only capable of tilt and vertical translation. It was used to develop the butterfly latches and magazine/socket interface. The second mockup used a gripper attached to an existing bridge robot. It was used to evaluate magazine designs and to prove that a magazine could be moved the length of a building without operator intervention and then precisely lowered through a canister throat without touching the throat sides. The final mockup [Figure 6] was a fully autonomous, freestanding robot that includes both rotations and the translation to seat a magazine in the socket. This demonstrated that the magazine can be locked into place inside a prototypical rack, and that the robot can load all seven rack positions without indexing the canister.

The final mockup is also being used to develop the user interface and control system for the three-degree-offreedom manipulator attached to the bridge robot. It is currently envisioned that the robot will obtain a loaded magazine from the staging area and lower it down into the canister under fully automatic control. Next, the operator will place the robot in a teleoperated mode and drive the magazine into a rack socket. Indexing from the first loaded magazine, the robot will then load the six remaining magazines without operator intervention. To enable this concept to be tested, the mockup had to be constructed to enable both fully automatic and teleoperation.

During teleoperation, the operator commands the robot from a console that has three joysticks and a touchpad. The operator can choose between tactile (joystick) and numeric (touchpad) operation in the teleoperated mode. The touchpad also allows the operator to choose fully or semi-automatic operation from a menu of automatic functions. To enable teleoperation, the robot is equipped with cameras and a light source, which can be

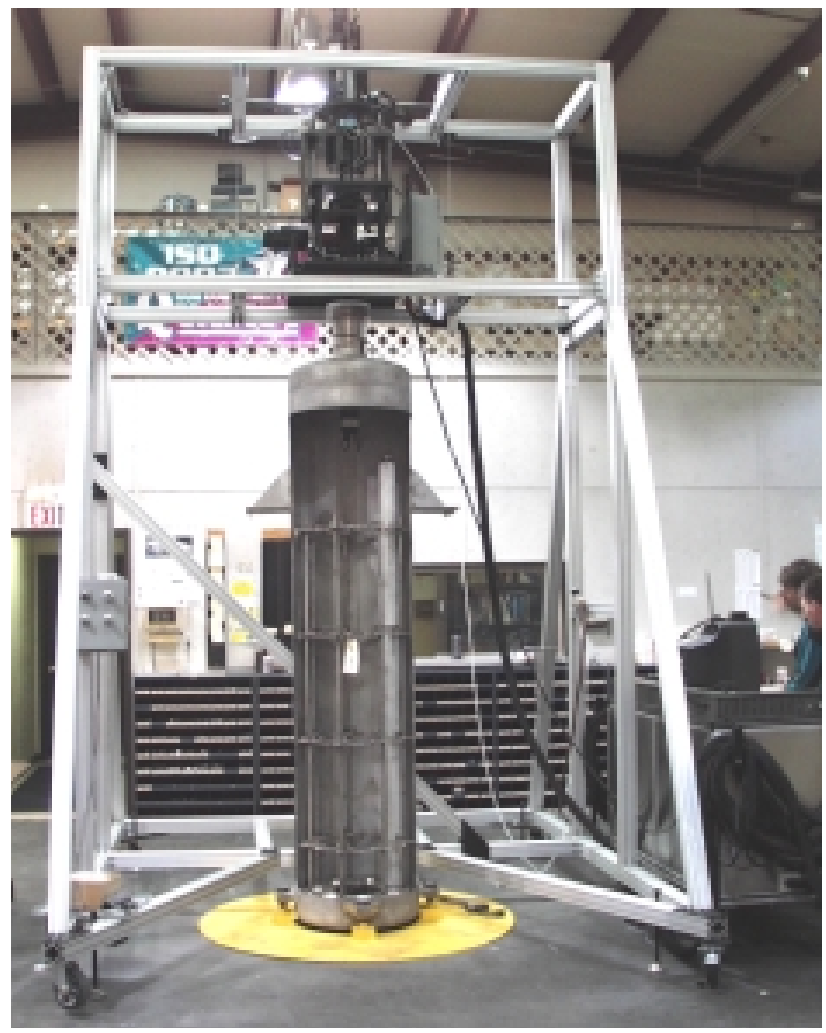

Figure 6: Freestanding Canister Loading Robot mockup 
seen in Figure 4.

To provide automatic operation, an Allen Bradley 504 series PLC controls all three axes of movement (vertical movement, arm rotation, and tilt.) Each servomotor has incremental encoder feedback so the system controls acceleration, position, and velocity for each motion. To avoid having to return to a "home" position following restarts, absolute encoders are also provided for each motor.

\section{PLANNED ACTIVITIES}

A second phase of cold pour testing at CETL is planned for FY 2000. These tests will echo the lessformal scoping tests performed in summer 1999, and will evaluate the performance of the selected can-in-canister hardware. These tests are intended to increase confidence in the hardware and are not expected to result in design changes. The development of other PIP equipment will continue through 2001, then SRTC will prepare a series of System Design Descriptions. These documents will become the design basis for the Architectural and Engineering Firm chosen to build the PIP facility.

\section{ACKNOWLEDGEMENTS}

Lee Hamilton is a Senior Mechanical Engineer in the Engineered Equipment and Systems Department in the Savannah River Technology Center (SRTC). [SRTC is the applied research and development laboratory at the SRS.] Dr. Gregory L. Hovis is a Principal Engineer in the SRTC Engineered Equipment and Systems Department, and Mitchell W. Stokes is a Fellow Engineer in the SRTC Engineered Equipment and Systems Department.

\section{REFERENCES}

M. W. Stokes, G. L. Hovis, E. L. Hamilton, J. B. Fiscus and R. H. Jones, 1999, "Magazine, Rack and Canister: Designing the Plutonium Immobilization Program System," Radwaste Magazine, pub. American Nuclear Society, Grange Park, IL., Vol. 6, No. 4, pp. 4954 